\title{
Effect of temperature and scarification on seed germination of Conanthera spp. (Tecophilaeaceae)
}

\author{
Carlos De la Cuadra ${ }^{1}$, Alexis K. Vidal ${ }^{1 *}$, Felipe Lagomarsino ${ }^{1}$, Patricia Peñaloza ${ }^{1}$, Leví M. Mansur ${ }^{1}$, \\ and Carlos Huenchuleo ${ }^{1}$
}

'Pontificia Universidad Católica de Valparaíso, Escuela de Agronomía, Casilla 4-D, Quillota, Chile.

"Corresponding author (kooichi.vidal@pucv.cl).

Received: 6 August 2018; Accepted: 10 January 2019; doi:10.4067/S0718-58392019000200323

\begin{abstract}
The Chilean endemic genus Conanthera is comprised of five species of herbaceous cormous geophytes. They have ornamental value due to their bell-shaped flowers, which are blue, violet or white. Previous germination studies of Conanthera campanulata and Conanthera trimaculata were carried out at $22{ }^{\circ} \mathrm{C}$, and manual mechanical scarification improved germination. Based on these results, it was suggested that physical dormancy is present in the non-scarified seeds. However, an improvement in germination after scarification is not enough evidence to conclude that the seed is non-permeable to water and thus has physical dormancy. The objective of the present study was to assess the testa water permeability via an imbibition test and to identify the optimum germination temperature in C. campanulata and C. trimaculata. Using 6-mo-old seeds, data from the imbibition tests showed that neither the seeds of $C$. campanulata nor $C$. trimaculata have physical dormancy. In the germination experiments, the temperature range for achieving high germination percentages was 10 to $15{ }^{\circ} \mathrm{C}$, where germination reached $90 \%$ in less than $28 \mathrm{~d}$. Temperature of $20{ }^{\circ} \mathrm{C}$ can be considered supra-optimal, while 5 and $25^{\circ} \mathrm{C}$ inhibited germination. Manual mechanical scarification did not affect germination results at the range of 10 to $15^{\circ} \mathrm{C}$. However, at the supra-optimal temperature of $20^{\circ} \mathrm{C}$ manual mechanical scarification increased germination, although levels were never higher than $25 \%$.
\end{abstract}

Key words: Conanthera campanulata, Conanthera trimaculata, germination temperature, imbibition, scarification, seed dormancy.

\section{INTRODUCTION}

Conanthera (Ruiz \& Pav.) is one of eight genera of Tecophilaeaceae (Simpson and Rudall, 1998), and it is comprised of five species: C. bifolia, C. campanulata, C. parvula, C. trimaculata and C. urceolata, which are endemic to Chile (Instituto de Botánica Darwinion, 2017). The genus has ornamental potential as a garden plant, pot plant and cut flower (Simpson and Rudall, 1998; Riedemann and Aldunate, 2001; Yáñez, 2001; Olate and Schiappacasse, 2013). The Conanthera species are perennial, herbaceous geophytes with tunicated corms; their leaves are basal, linear and glabrous; the inflorescence is a panicle with bell-shaped flowers with six straight or reflex blue, violet or white tepals, with or without spots; and the fruit is comprised of round tri-valve capsules, which produce black, opaque, ovoid seeds in variable numbers depending on the species (Muñoz, 2000). The conservation status is determined as of little concern for C. campanulata, while C. urceolata is at risk, and C. bifolia, C. parvula and C. trimaculata have not been evaluated (Ministerio del Medio Ambiente, 2017).

These species are common on sunny hillsides with well-drained soils (Riedemann and Aldunate, 2001), as well as in clearings and on slopes of sclerophyllous forests and shrublands (Teillier et al., 2005). According to Buerki et al. (2013), the habitats of Conanthera species are arid climates (C. campanulata and C. urceolata) or Mediterranean climates $(C$. bifolia, C. campanulata, C. trimaculata and C. parvula). In both of these climates, adult corms sprout and grow in 
autumn and winter, flowering occurs in spring, and seeds are dispersed during summer. The summer in these regions is characterized by absence of rainfall. According to Baskin and Baskin (2014), seeds of herbaceous species in these climates can be categorized into predominantly having physiological dormancy $(65 \%)$, followed by physical dormancy (20\%) or other types of dormancy (12\%), and a few having no dormancy (3\%).

The germination requirement of some Conanthera species have been studied. Schiappacasse et al. (2005) found that $C$. bifolia requires stratification at $8{ }^{\circ} \mathrm{C}$ for 6 wk with subsequent germination at 15 and $20{ }^{\circ} \mathrm{C}$, thus assuming the occurrence of physiological dormancy (Baskin and Baskin, 2014). Vogel et al. (1999) stated that for seeds of $C$. campanulata and C. trimaculata stored for 8- and 11-mo manual mechanical scarification improved germination at $22{ }^{\circ} \mathrm{C}$. Based on this result, Vogel et al. (1999) suggested the presence of physical dormancy in seeds of these two species. However, Baskin and Baskin (2014) have explained that increased germination after scarification is not enough evidence to prove that seeds have physical dormancy, and thus an imbibition test is required to determine the presence or absence of physical dormancy.

The present study focuses on seed imbibition and determining the optimum temperature required for germination of C. campanulata and C. trimaculata. These results are important for the domestication, conservation and development of genetic improvement programs for these species.

\section{MATERIALS AND METHODS}

\section{Seed origin}

Seeds of Conanthera campanulata and C. trimaculata were collected at the end of February 2016 from dehiscent capsules from populations of plants growing in their natural habitats. Sampling of C. campanulata was done at Catapilco ( $32^{\circ} 31^{\prime}$ $\mathrm{S}, 71^{\circ} 17^{\prime} \mathrm{W}$ ), inland from Zapallar, Chile. This area is classified as semi-arid subtropical Mediterranean climate (Novoa and Villaseca, 1989) as shown in Figure 1A. Sampling of C. trimaculata was done at Laguna Verde ( $\left.33^{\circ} 06^{\prime} \mathrm{S}, 71^{\circ} 40^{\prime} \mathrm{W}\right)$, a coastal area near Valparaíso, Chile. Its climate is classified as marine Mediterranean (Novoa and Villaseca, 1989), as shown in Figure 1B. Moreover, both areas, during the period from 1979 to 2015 have not shown significant warming trends due climate change (Burger et al., 2018). After seeds were collected, they were stored in paper envelopes at $20 \pm 5^{\circ} \mathrm{C}$ for 6-mo until imbibition (Experiment 1) and germination (Experiment 2) tests were carried out.

\section{Experiment 1 - Imbibition tests}

The imbibition tests of $C$. campanulata and $C$. trimaculata non-scarified and manual mechanically scarified seeds were carried out in a growth chamber at $15{ }^{\circ} \mathrm{C}$ in dark conditions. The manual mechanical scarification consisted in uniform abrasion around all seed surface with 80 grit wood sandpaper, removing the testa evenly until the endosperm was slightly

Figure 1. Climographs of subtropical semiarid Mediterranean climate (A) and marine Mediterranean climate (B) corresponding to the collection sites of Catapilco $\left(32^{\circ} 31^{\prime} \mathrm{S}, 71^{\circ} 17^{\prime} \mathrm{W}\right)$ and Laguna Verde $\left(33^{\circ} 06^{\prime} \mathrm{S}, 71^{\circ} 40^{\prime} \mathrm{W}\right)$ for the Conanthera campanulata and C. trimaculata seeds, respectively. Adapted from Novoa and Villaseca (1989).
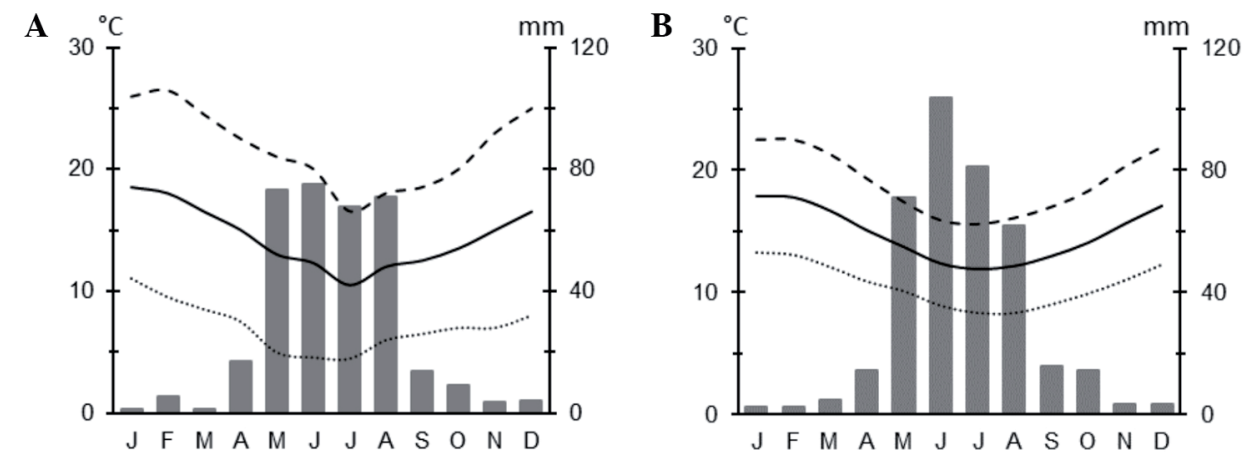

Solid bars: Precipitation, solid line: average monthly temperature, dashed line: maximum monthly temperature, dotted line: minimum monthly temperature. 
visible, avoiding seed damage (Mousavi et al., 2011). For each species, the experiment was arranged in a completely randomized design with three replicates of 25 seeds. The seeds in each replicate were weighed after $0,6,24$, and $48 \mathrm{~h}$ of imbibition. Ten replicates of 100 seeds of each of the four cultivars were weighed using an electronic balance (model BP210S, Sartorius, Göttingen, Germany).

The relative seed mass increase by each replicate after each imbibition period was calculated using the equation: $\% W i=((W i-W f) / W f) \times 100$, where $W i$ and $W f$ are the weight of imbibed and non-imbibed seeds, respectively (Shalimu et al., 2015). The relative seed mass increase was analyzed by ANOVA for each species. To compare the different treatments, the Tukey test was used with $P \leq 0.05$. Prior to the ANOVA test, the data were arcsine transformed to satisfy the assumptions of ANOVA (Walpole et al., 2012). The data were analyzed using Minitab 17 (Minitab Inc., State College, Pennsylvania, USA).

\section{Experiment 2 - Germination tests}

For each species, germination tests also were conducted for non-scarified and manual mechanically scarified seeds using a completely randomized experimental design. The manual mechanical scarification was carried out as described in Experiment 1. Before sowing, non-scarified and mechanically scarified seeds were disinfected for 3 min in a solution of $1 \%$ captan ( $N$-(trichloromethylthio)-4-cyclohexene-1,2-dicarboximide; Captan 50WP, Arysta LifeScience North America, Cary, North Carolina, USA) and then rinsed three times.

Germination tests of non-scarified seeds were carried out in growth chambers at $5,10,15,20$ and $25 \pm 2{ }^{\circ} \mathrm{C}$, under dark conditions. For manual mechanically scarified seeds, germination tests were carried out only at 10,15 and $20 \pm 2{ }^{\circ} \mathrm{C}$ due to limitations of seeds. Each treatment had three replicates of 25 seeds each, which were placed in a $9 \mathrm{~cm}$ diameter Petri dish with absorbent paper soaked with 3 to $4 \mathrm{~mL}$ distilled water. The germination records were taken every $2 \mathrm{~d}$ for a maximum period of $4 \mathrm{wk}$. Seeds were exposed to room light while checking for germination. A seed was considered germinated when the radicle had emerged to a length of at least $2 \mathrm{~mm}$. If seeds did not reach $85 \%$ germination in at least one of the temperature treatments at each storage months, a tetrazolium test was performed to control seed viability (International Seed Testing Association, 2003).

The germination data for each treatment was fit to the event-time model $F(t)=d /\left(1+\exp \left[b\left\{\log (t)-\log \left(t_{50}\right)\right\}\right]\right)$ used by Ritz et al. (2013), where $F$ defines a proper cumulative distribution function which, for each time point $t \geq 0$, returns the fraction of seeds that have already germinated. The upper limit parameter $d$ denotes the proportion of seeds that germinated during the experiment out of the total number of seeds present at the beginning of the experiment. The parameter $b$ is proportional to the slope of $\mathrm{F}$ at time $t$ equal to the parameter $t_{50}$, this last parameter being the time elapsed in order to reach $50 \%$ germination of the maximum germination percentage.

For parameter estimation of the event-time model for each treatment, the extension package for the software environment $\mathrm{R}$ was used (Ritz and Streibig, 2005). The statistical test used for comparisons was the test of equality of two means when population variances are nor equal at $P \leq 0.05$ (Ritz and Streibig, 2005).

\section{RESULTS}

\section{Experiment 1 - Imbibition tests}

The mass of seeds varies depending on the species. Conanthera campanulata seeds had an average mass of $1.67 \pm 0.11 \mathrm{~g}$ per 1000 seeds, $C$. trimaculata seeds an average of $2.85 \pm 0.14 \mathrm{~g}$ per 1000 seeds. Manual mechanical scarification reduced their average mass by $8 \%$ and $10 \%$, respectively.

For both species, there is a significant interaction between scarification and imbibition time on the relative seed mass increase (Table 1). Such an interaction was only observed at $6 \mathrm{~h}$ of imbibition, where the increase in relative seed mass of non-scarified was always under $48 \%$, while for manual mechanically scarified seeds it was higher than $58 \%$. After $48 \mathrm{~h}$ of imbibition, the relative seed mass increase was greater than $80 \%$, irrespective whether the seed was scarified or not. As imbibition time increased beyond $6 \mathrm{~h}$, there was no difference in the relative seed mass between treatments (Figure 2).

\section{Experiment 2 - Germination tests}

Germination curves for the different treatments were fit to the model used by Ritz et al. (2013) (Figure 3). For nonscarified seeds stored for 6-mo, the highest values for the upper limit parameter $\mathrm{d}$ were obtained at 10 and $15^{\circ} \mathrm{C}$ for both 
species. The values of $\mathrm{t}_{50}$ at 10 and $15^{\circ} \mathrm{C}$ showed differences, but not the values of $\mathrm{b}$ (slope at time $\mathrm{t}_{50}$ ) for C. campanulata and $C$. trimaculata. At 5,20 , and $25^{\circ} \mathrm{C}$, after $28 \mathrm{~d}$, the final germination percentage was zero or less than $5 \%$ (Table 2).

A similar result was observed for mechanically scarified seeds stored for 6-mo. The highest values of $\mathrm{d}$ were obtained at 10 and $15{ }^{\circ} \mathrm{C}$, and the values of the other variables showed similar results. Germination was also zero at 5 and $25{ }^{\circ} \mathrm{C}$ after $28 \mathrm{~d}$. For $C$. trimaculata, there were no differences in germination at $20^{\circ} \mathrm{C}$ for scarified and non-scarified seeds. However, there was an effect of scarification on C. campanulata at $20^{\circ} \mathrm{C}$, although the final germination percentage (d) of mechanically scarified seeds was not higher than $25 \%$ (Table 2).

\section{DISCUSSION}

Indistinct if the seeds were non-scarified or mechanically scarified, germination was high $(\mathrm{d}>85 \%)$ for at least one germination temperature for each species. Based on this result, disinfection treatment before sowing was assumed harmless and as having no effect on viability of the seed. So a tetrazolium test was not required and although light requirement for germination is unknown, if there was any, it would have been fulfilled during seed germination evaluation, which was performed under room light conditions.

The testa of the seeds of C. campanulata and C. trimaculata stored for 6-mo did not confer physical resistance to water entry. This would mean that, unlike the findings of Vogel et al. (1999), the seeds of C. campanulata and C.trimaculata do not have physical dormancy. In addition, we can reconfirm the findings of Baskin and Baskin (2014) in that the effective way to determine physical dormancy in seeds is through imbibition testing. A similar characteristic of testa not conferring physical resistance to water entry can also be seen on C. bifolia, Zephyra compacta, Z. elegans and Z. violiflora, all of which are in the Tecophilaeaceae (Schiappacasse et al., 2005; Vidal et al., 2012; De la Cuadra et al., 2017).

Table 1. Mean squares for relative seed mass increase of Conanthera spp. non-scarified and mechanically scarified seeds after 6, 24, and $48 \mathrm{~h}$ imbibition.

\begin{tabular}{lccc}
\hline Source & DF & $\begin{array}{c}\text { Conanthera } \\
\text { campanulata } \\
\text { MS }\end{array}$ & $\begin{array}{c}\text { Conanthera } \\
\text { trimaculata } \\
\text { MS }\end{array}$ \\
\hline Scarification (S) & 1 & $0.0 \mathrm{~ns}$ & $485.8^{* *}$ \\
Imbibition (I) & 2 & $455.4^{* * *}$ & $882.4^{* * *}$ \\
S $\times$ I & 2 & $142.4^{* * *}$ & $122.5^{*}$ \\
Error & 12 & 10.5 & 34.0 \\
\hline
\end{tabular}

DF: Degrees of freedom; MS: mean squares.

$*, * *, * * *$ Significant at the $0.05,0.01$ and 0.001 probability levels, respectively, by the $\mathrm{F}$ test; ns: nonsignificant.

Figure 2. Imbibition curves for non-scarified (solid line) and mechanically scarified (dashed line) seeds of Conanthera campanulata (A) and C. trimaculata (B) at $15^{\circ} \mathrm{C}$.
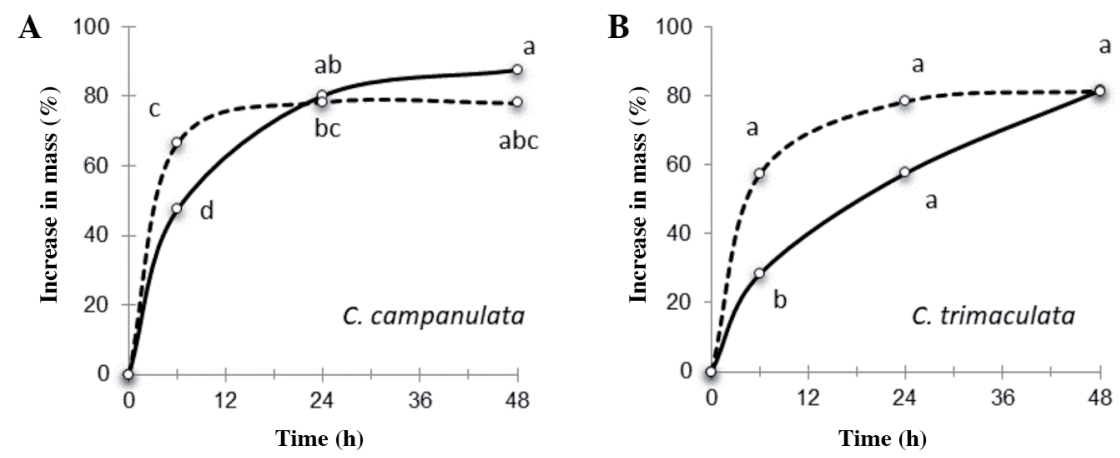

Means followed by the same letter in each graph showed non-significant differences according to the Tukey test $(\mathrm{P} \leq 0.05)$. 
Figure 3. Example of typical germination curves fit to the event-time model (solid line). According to Ritz et al. (2013), the model equation is $d /\left(1+\exp \left[b\left\{\log (t)-\log \left(t_{50}\right)\right\}\right]\right)$ where $t_{50}$ is the time elapsed to reach $50 \%$ germination relative to the maximum germination percentage, which is the upper limit $d$ of the germination curve. The slope of the germination curve at time $t_{50}$ is proportional to $b$ (with a proportionality constant that depends on $d$ and $t_{50}$ ). The interpretations of the parameter estimates are shown with dotted lines in the figure.

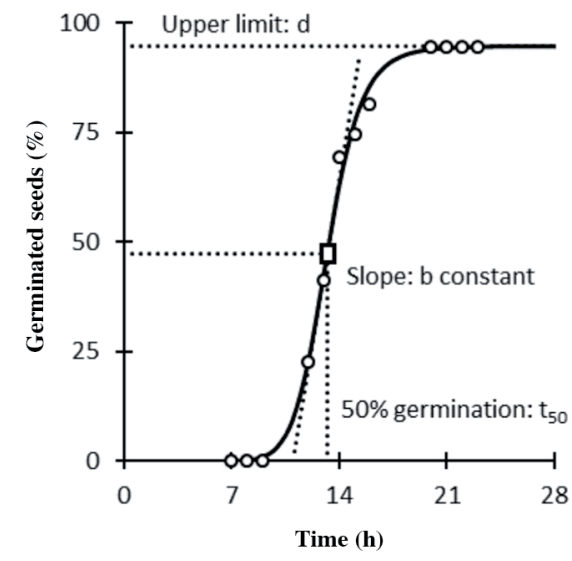

Six-month-old non-scarified seeds of Conanthera trimaculata germinated at $10{ }^{\circ} \mathrm{C}$.

Table 2. Parameter estimates (standard errors in brackets) of the log-logistic model $d /\left(1+\exp \left[b\left\{\log (t)-\log \left(t_{50}\right)\right\}\right]\right)$ obtained by fitting the event-time model on Conanthera spp. seeds stored for 6-mo before sowing. The upper limit parameter d denotes the proportion of seeds that germinated during the experiment, $t_{50}$ denotes the time by which $50 \%$ of the seeds that germinated during the experiment have germinated, and $b$ denotes the slope of the germination curve at time $t_{50}$.

\begin{tabular}{|c|c|c|c|}
\hline $\begin{array}{l}\text { Germination } \\
\text { temperature, }{ }^{\circ} \mathrm{C}\end{array}$ & d & $\mathrm{t}_{50}$ & $\mathrm{~b}$ \\
\hline \multicolumn{4}{|c|}{ Conanthera campanulata, non-scarified seeds } \\
\hline 5 & 0 & & \\
\hline 10 & $97(2) \mathrm{aA}$ & $11.4(0.2) \mathrm{bB}$ & $-11.3(1.3) \mathrm{aAB}$ \\
\hline 15 & $96(2) \mathrm{aA}$ & $8.0(0.1) \mathrm{aA}$ & $-15.8(1.8) \mathrm{aA}$ \\
\hline 20 & 0 & & \\
\hline 25 & 0 & & \\
\hline \multicolumn{4}{|c|}{ Conanthera campanulata, mechanically scarified seeds } \\
\hline 10 & $99(1) \mathrm{aA}$ & $10.5(0.3) \mathrm{bB}$ & $8.1(0.8) \mathrm{aB}$ \\
\hline 15 & 99 (1)aA & $8.1(0.1) \mathrm{aA}$ & $-11.6(1.3) \mathrm{aAB}$ \\
\hline 20 & $27(6) \mathrm{bB}$ & $10.3(3.2) \mathrm{abAB}$ & $-1.9(0.5) \mathrm{bC}$ \\
\hline \multicolumn{4}{|c|}{ Conanthera trimaculata, non-scarified seeds } \\
\hline 5 & 0 & & \\
\hline 10 & $95(3) \mathrm{aA}$ & $13.2(0.2) \mathrm{bB}$ & $-11.8(1.4) \mathrm{aA}$ \\
\hline 15 & $94(3) \mathrm{aA}$ & $11.0(0.3) \mathrm{aA}$ & $-8.4(0.9) \mathrm{abAB}$ \\
\hline 20 & $4(3) \mathrm{bB}$ & 10.7 (3.6)abAB & $-3.8(2.4) \mathrm{bB}$ \\
\hline 25 & 0 & & \\
\hline \multicolumn{4}{|c|}{ Conanthera trimaculata, mechanically scarified seeds } \\
\hline 10 & 97 (2)aA & $13.1(0.3) \mathrm{bB}$ & $-8.3(0.9) \mathrm{aAB}$ \\
\hline 15 & $94(3) \mathrm{aA}$ & $11.5(0.3) \mathrm{aA}$ & $-7.4(0.8) \mathrm{aB}$ \\
\hline 20 & $19(11) \mathrm{bB}$ & $20.5(13.2) \mathrm{abAB}$ & $-2.0(0.2) \mathrm{bC}$ \\
\hline
\end{tabular}

For each species and scarified treatment, mean values within a column followed by the same lower-case letter do not differ significantly $(\mathrm{P} \leq 0.05)$ according to a test of equality of two means when population variances are not equal.

Mean values within a column of each species followed by the same capital letter do not differ significantly $(\mathrm{P} \leq 0.05)$ according to a test of equality of two means when population variances are not equal. 
The temperature range for achieving high germination percentages for $C$. campanulata and $C$. trimaculata is between 10 and $15{ }^{\circ} \mathrm{C}$. When analyzing variable $\mathrm{t}_{50}$ (time where $50 \%$ of the seeds that germinated during the experiment have germinated) for $C$. campanulata and $C$. trimaculata, the optimum temperature is $15{ }^{\circ} \mathrm{C}$. For both species, $20{ }^{\circ} \mathrm{C}$ is considered supra-optimal. Five and $25^{\circ} \mathrm{C}$ are outside the temperature range that allows seeds of the two study species to germinate. The seeds of $C$. campanulata and C. trimaculata have a behavior similar to that of a winter annual species, i.e. they germinate in winter and plants senesce in spring or summer, after seed set. Similar behavior is seen in other Mediterranean geophytes from Chile, such as Leucocoryne spp., Trichopetalum plumosum, Pasithea coerulea and Schizanthus litoralis (Jara et al., 2006; De la Cuadra et al., 2016) and others geophytes as Crocus spp., Narcissus spp., Scilla autumnalis and Urginea maritima (Marques and Draper, 2012; Skourti and Thanos, 2015).

According to Figueroa et al. (2004), the region of central Chile with a Mediterranean climate (from $30^{\circ}$ to $37^{\circ} \mathrm{S}$ lat) is characterized by the presence of many species that respond to mechanical or chemical scarification of their seeds. However, manual mechanical scarification has no effect on the germination of C. campanulata and C. trimaculata in the temperature range of 10 to $15{ }^{\circ} \mathrm{C}$. Only when germinating at the supra-optimal temperature of $20{ }^{\circ} \mathrm{C}$ does scarification increase germination, although the level achieved is rather low, not exceeding $25 \%$. At the supra-optimal temperature of $22^{\circ} \mathrm{C}$, a similar effect has been reported by Vogel et al. (1999) for seeds of C. campanulata and C. trimaculata.

There is no evidence that 6-mo storage at $20 \pm 5^{\circ} \mathrm{C}$ has a detrimental effect on the viability of seeds of $C$. campanulata and C.trimaculata, as germination was over $93 \%$. It is probable that the Conanthera seeds studied here are to be categorized as orthodox and show a high degree of longevity under storage. This has also been observed with others Mediterranean species in Chile such as Alstroemeria spp., Calceolaria spp., Leucocoryne spp. and Nolana paradoxa (Hong et al., 1998; De la Cuadra et al., 2002) and species from others Mediterranean regions (Juan-Vicedo et al., 2016).

The results reported in this manuscript are for 6-mo-old seeds, potentially after-ripened, and future studies using fresh seeds may not result in high germination percentages at 10 or $15^{\circ} \mathrm{C}$. It is not possible to discard that seeds were dormant at maturity and may have after-ripened during storage, it means that $C$. campanulata and $C$. trimaculata could have physiological dormancy.

\section{CONCLUSIONS}

The results of this study show that the seeds of Conanthera campanulata and C. trimaculata have no physical dormancy, and the temperature requirements for germination of 6-mo-old seeds, which are 10 to $15{ }^{\circ} \mathrm{C}$, match those annual winter species that grow in the same Mediterranean habitats.

\section{ACKNOWLEDGEMENTS}

We gratefully acknowledge Andrés Ramm for providing seeds of Conanthera trimaculata used in this research. Furthermore, the authors appreciate the help of Michail Belov on sharing his observational experience with C.trimaculata.

\section{REFERENCES}

Baskin, C.C., and Baskin, J.M. 2014. Seeds: Ecology, biogeography, and evolution of dormancy and germination. $2^{\text {nd }}$ ed. Academic Press, San Diego, California, USA.

Buerki, S., Manning, J.C., and Forest, F. 2013. Spatio-temporal history of the disjunct family Tecophilaeaceae: a tale involving the colonization of three Mediterranean-type ecosystem. Annals of Botany 111:361-373. doi:10.1093/aob/mcs286.

Burger, F., Brock, B., and Montecinos, A. 2018. Seasonal and elevational contrasts in temperature trends in Central Chile between 1979 and 2015. Global and Planetary Change 162:136-147. doi.org/10.1016/j.gloplacha.2018.01.005.

De la Cuadra, C., Mansur, L., Verdugo, G., and Arriagada, L. 2002. Deterioration of Leucocoryne spp. seeds as a function of storage time. Agricultura Técnica 62:46-55. doi.org/10.4067/S0365-28072002000100005.

De la Cuadra, C., Vidal,A.K., Lefimil, S., and Mansur, L. 2016. Temperature effect on seed germination in the genus Leucocoryne (Alliaceae). HortScience 51:412-415.

De la Cuadra,C., Vidal,A.K., and Mansur,L.M. 2017. Optimal germination temperature for Zephyra compacta (Tecophilaeaceae). HortScience 52:432-435. doi:10.21273/HORTSCI11623-16. 
Figueroa, J.A., León-Lobos, P., Cavieres, L.A., Pritchard, H.W., y Way, M. 2004. Ecofisiología de semillas en ambientes contrastantes de Chile: un gradiente desde ecosistemas desérticos a templado-húmedos. p. 81-98. In Cabrera, M. (ed.) Fisiología ecológica y evolutiva de plantas: mecanismos y respuestas a estrés en los ecosistemas. Ediciones Universidad de Valparaíso, Valparaíso, Chile.

Hong, T.D., Linington, S., and Ellis, R.H. 1998. Compendium of information on seed storage behaviour. Royal Botanic Gardens, Kew, UK.

Instituto de Botánica Darwinion. 2017. Flora of Southern South America/Flora del Cono Sur. Instituto de Botánica Darwinion, Buenos Aires, Argentina. Available at http://www2.darwin.edu.ar/ (accessed July 2017).

International Seed Testing Association. 2003. ISTA working sheets on tetrazolium testing. Vol. I. International Seed Testing Association (ISTA), Bassersdorf, Switzerland

Jara, P., Arancio, G., Moreno, R., and Carmona, M. 2006. Abiotic factors effects influencing the germination of six herbaceous species of Chilean arid zone. Revista Chilena de Historia Natural 79:309-319. doi:10.4067/S0716-078X2006000300003.

Juan-Vicedo, J., Fernández-Pereira, J., Ríos, S., Casas, J.-L., and Martín, I. 2016. Seed germination and storage behaviour of Lapiedra martinezii (Amaryllidaceae). Seed Science and Technology 44:199-206. doi:10.15258/sst.2016.44.1.02.

Marques,I., and Draper, D. 2012. Seed germination and longevity of autumn-flowering and autumn-seed producing Mediterranean geophytes. Seed Science Research 22:299-309. doi:10.1017/S0960258512000153.

Ministerio del Medio Ambiente. 2017. Especies, clasificación según estado de conservación. Ministerio del Medio Ambiente, Gobierno de Chile, Santiago, Chile. Available at http://www.mma.gob.cl/clasificacionespecies/index2.htm (accessed February 2017).

Mousavi, S.R., Rezaei, M., and Mousavi, A. 2011. A general overview on seed dormancy and methods of breaking it. Advances in Environmental Biology 5:3333-3337.

Muñoz, M. 2000. Consideraciones sobre los géneros endémicos de monocotiledóneas de Chile. Noticias Mensuales Museo Nacional de Historia Natural 343:16-27.

Novoa, R., y Villaseca, S. 1989. Mapa agroclimático de Chile. Instituto de Investigaciones Agropecuarias (INIA), Santiago, Chile.

Olate, E.A., and Schiappacasse, F. 2013. Geophyte research and production in Chile. p. 449-469. In Kamenetsky, R., and Okubo, H. (eds.) Ornamental geophytes: from basic science to sustainable production. CRC Press, London, UK. doi:10.1201/b12881-17.

Riedemann, P., y Aldunate, G. 2001. Flora nativa de valor ornamental, identificación y propagación, Chile zona centro. Editorial Andrés Bello, Santiago, Chile.

Ritz, C., Pipper, C.B., and Streibig, J.C. 2013. Analysis of germination data from agricultural experiments. European Journal of Agronomy 45:1-6. doi:10.1016/j.eja.2012.10.003.

Ritz, C., and Streibig, J.C. 2005. Bioassay analysis using R. Journal of Statistical Software 12. URL Available at http://www.bioassay.dk (accessed July 2017).

Schiappacasse, F., Peñailillo, P., Yañez, P., and Bridgen, M. 2005. Propagation studies on Chilean geophytes. Acta Horticulturae 673:121-126. doi:10.17660/ActaHortic.2005.673.13.

Shalimu, D., Li, K., Baskin, C.C., Baskin, J.M., and Liu, Y. 2015. Seed germination biology of four pomegranate (Punica granatum) cultivars from Xinjiang, China. HortScience 50:826-829.

Skourti, E., and Thanos, C.A. 2015. Seed afterripening and germination photoinhibition in the genus Crocus (Iridaceae). Seed Science Research 25:306-320. https://doi.org/10.1017/S0960258515000264.

Simpson, M.G., and Rudall, P.J. 1998. Tecophilaeaceae. p. 429-436. In Kubitzki, K. (ed.) The families and genera of vascular plants. Volume III. Flowering plants, Monocotyledons: Lilianae (except Orchidaceae). Springer, Heidelberg, Germany. doi:10.1007/978-3-662-03533-7.

Teillier, S., Aldunate, G., Riedemann, P., y Niemeyer, H. 2005. Flora de la Reserva Nacional Río Clarillo. Impresos Socías Ltda., Santiago, Chile.

Vidal, A.K., Han, D.S., Nakano, M., and Niimi, Y. 2012. Decreased time from seed to flowering corm size in Zephyra elegans via in vitro cultivation. Ciencia e Investigación Agraria 39:577-584. doi:10.4067/S0718-16202012000300017.

Vogel, H., Schiappacasse, F., Valenzuela, M., and Calderón, X. 1999. Studies of generative and vegetative propagation in Conanthera spp. Ciencia e Investigación Agraria 26:21-26.

Walpole, R.E., Myers, R.H., Myers, S.L., and Ye, K. 2012. Probability and statistics for engineers and scientists. $9^{\text {th }}$ ed. Prentice Hall, Boston, Massachusetts, USA.

Yáñez,P. 2001. Estudios biológicos para el uso ornamental de la geófita chilena Conanthera bifolia Ruiz et Pavon (Tecophilaceae). MS Tesis. Universidad de Talca, Facultad de Ciencias Agrarias, Talca, Chile. 